\title{
Juridical Study Regarding the Judge's Decision on the Case of Premeditated Murder
}

\author{
Eddy Herwani ${ }^{1}$, Suparno $^{2}$ \\ \{didiedmahaswara29@gmail.com ${ }^{1}$, suparno@borobudur.ac.id² \\ Universitas Borobudur, Jakarta, Indonesia ${ }^{1,2}$
}

\begin{abstract}
Premeditated murder is a very heinous crime, considering it is beyond humanity. Taking other people's lives because of certain things, of course, there are many factors behind the occurrence of this premeditated murder. The method used in this research is normative juridical with a literature study approach that examines judges' decisions in cases of premeditated murder. This study reveals two factors behind the occurrence of the judge's decision in litigation, namely internal and external factors. The conclusion obtained from this study is the judge's consideration in deciding cases of premeditated murder, according to the rights and authorities of judges according to Law number 4 of 2004 concerning the judiciary.
\end{abstract}

Keywords: Judge's Decision; Premeditated Murder; Criminal Case

\section{Introduction}

The Criminal Code is the primary legal source of Indonesia's positive criminal law, which regulates the general rules of criminal law in book one and the formulations of criminal acts set out in books two and three.[1] The general rules in criminal law contain the principles of various things, including eliminating, reducing, incriminating the criminal on trials, concurrently, on participation, and so on.

Criminal acts in the Criminal Code are divided into 2 (two) crimes related to objects as legal objects and offenses related to persons or entities as legal subjects.[2] Most of the crimes that occur in society are related to the bodies and lives of people. Almost every day on television and in newspapers, some actions always attack the body and life. Usually, this is done in groups or individuals who turn into anarchists.[3]

Efforts to establish and foster legal awareness in the community must be carried out because there is a higher level of legal knowledge of the community.[4] The Criminal Code, which is the primary source of material criminal law, contains general rules of criminal law and formulations of certain criminal acts.[5] The existence of a criminal threat against a person who violates the prohibition of committing an act as formulated in the act as a feature of a particular criminal act distinguished from the rules concerning the prohibition of other actions that are not criminal. A show that is considered a crime is formulated in a law viewed as an act that endangers a legal interest. Establishing a prohibition against committing an act accompanied by threats or criminal sanctions for those who violate it means that the law has provided legal protection for legal interests.[6] 
Deliberate murder is killing by arranging in advance. In other words, it is planned by using a tool that kills the victim-killing intentionally because the person already has the intention or plan to kill by using the tools or items used to kill someone. The occurrence of robbery accompanied by stabbing, shooting, killing other people is referred to as murder. The intervention of the government and the state against each individual is a must. In criminal law, the size of the danger to the interests of the community and the state is set for creating an offense. The interests of the community and the state are upheld above the interests of the individual.

The life of the Indonesian nation is based on Pancasila.[7] There are two principles in Pancasila, namely the principle of human life against the will of God Almighty as the creator of the universe and the principle of equality between humans as members of society, not individuals.[8] Pancasila is an equal and equal interaction relationship between fellow members of the community.

Strict criminal law can cause criminal law to be easily used as a tool of power and a weapon of conflict between humans. The determining factor of criminal law is used as a tool of power or is not focused on the philosophy of life of the nation, while the other factor is the human factor as a legal actor.

The number of criminal cases committed by humans in the surrounding environment, seen based on field observations, occur due to influencing factors, including low education, high poverty, unemployment which causes individuals as humans to choose ways to get things with actions that include: in criminal acts which are strictly prohibited by law and the arrangements have been determined.

Killing is an act that is prohibited by religion and in the norms of society based on no models that teach and allow someone to commit murder. Every existing model teaches to respect and protect the rights of human life. For example, in religious teachings, the act of killing is also prohibited. This prohibition against killing includes abortion, euthanasia, and suicide, but if the killing is due to self-defense against the attacks of others, it is permissible. This prohibition of killing, when interpreted broadly, means avoiding war to prevent significant bloodshed.[9]

Murder is regulated in the criminal code of law as written in Articles 338 to 350, where there are ordinary and premeditated murders. Premeditated murder has a criminal penalty such as death threats, life imprisonment, or a maximum of 20 (twenty) years.

The judge in making the decision must take full consideration so that there is no unilateral sense of injustice, such as the case experienced by Antasari, how there is no substantial evidence that he is a suspect in the murder of Nazzarudin. This case is controversial because it is suspected that the KPK has criminalized it. The judge's injustice was seen when he sentenced Antasari to a premeditated murder with 18 years in prison. The role of a judge dramatically influences the decision he will make because, in the courtroom, it is the role of the judge who has the power in the end.

\section{Methods}

The approach method used in this study is a qualitative approach that emphasizes understanding the formulation of the problem. Approach by collecting data sourced from secondary data in the form of documents or library materials. Secondary legal materials are closely related to primary legal materials, namely draft laws and regulations, scientific works of scholars, or research results.[10] 
The problem in this study is that the authors use the research specifications in a descriptive analysis, which describes the sources' views on the verdict of the crime of premeditated murder. The data collected in this research was carried out utilizing a literature study that would study legal materials, study the actual situation in the field, and interview informants related to the research title. Data that has been obtained from further research is collected and processed to be codified. After doing all of that sequence, to answer the problem formulation, it is necessary to arrange it systematically in the form of a description of the answers.

\section{Discussion}

\subsection{Legal Protection for Workers}

Judges as law enforcers who make decisions in each trial determine whether the person who commits the crime can be said to be a suspect or not. Of course, as a judge, he must have high integrity in resolving or deciding a case in court without any intervention from outside parties. Judges must be honest and impartial to anyone so that their decisions are accurate to provide justice.

The issue of punishment is the judge's authority. In making his decision, the judge needs to have sensitive feelings, meaning that he must judge appropriately and objectively according to community justice. Judges in making their decisions on cases of premeditated murder are very diverse, meaning that they can vary according to the chronology of the case but still refer to the applicable law. The sentence that the judge can impose following Article 340 of the Criminal Code related to this case is the death penalty, life imprisonment, or a maximum of 20 years in prison, but fewer than these sentences are.

In Semarang, there were cases of premeditated murder, either alone or together. Murders that are covered with planning make the perpetrators think carefully about carrying out executions. The following is all information on the judge's decision in a premeditated murder at the Semarang District Court.

The death penalty and the lifelong sentence have never happened, especially in the Semarang City District Court. Sentences in which there are more than one article and even 3 to 4 pieces can lead to life sentences and even death sentences imposed by the judge.

Judges in considering decisions must have a strong basis so that in making their decisions, they can be fair and accepted by all parties. The sentence handed down by the judge to the defendant must have strong evidence, fulfill the elements, and follow the trial's facts. The aspects in premeditated murder include:

1. Whose element

2. Elements on purpose

3. Features are planned in advance

4. Details of taking people's lives

5. Characteristics of people who do, ordered to do, and people who participate in doing.

The judge, in considering the imposition of a decision, must be based on the facts in the trial with correct evidence, namely: Witness testimony, Letter, and Defendant's statement. Judges in giving criminal sentences should consider:

1. Maker error

2. The motive and purpose of committing a crime

3. How to do it

4. The defendant's mental attitude 
5. His life and socio-economic history

6. The defendant's perspective and actions after committing

7. The public's view of the actions taken by the defendant

8. Criminal effect for the defendant's future

9. Influence on the victim and the victim's family

10. A criminal act committed with a plan

The murder committed by the perpetrator has fulfilled the elements of a case of premeditated murder in Article 340 of the Criminal Code, namely anyone who, intentionally, premeditated, took another person's life. The acts committed by the suspect fulfill these elements, namely as follows:

a. Whose element? Every person or legal subject who commits a criminal act can be held accountable for his actions.

b. Deliberate element, the defendant had the intention to commit a criminal act, which resulted in a person's death. The intentional element can be concluded that there are a person's heart attitude and intentions, without any encouragement or coercion from other parties. The purpose in question is the existence of a plan from him themselves to take the lives of others. The judge judged that the murder was premeditated.

\subsection{Barriers to Judges in Giving Decisions}

Judges in considering decisions in court sometimes find obstacles that result in judges not making decisions in criminal acts of premeditated murder. If there are inhibiting factors in the judge giving his decision, it will automatically affect the success of the judge in making his decision. These obstacles can arise due to situations created by various parties, both intentional and unintentional.

In general, the obstacles faced by judges in giving their decisions in deciding the crime of premeditated murder are caused by 2 (two) factors, namely:

\section{a) Internal Factors}

Internal factors are factors that occur from within the judge himself. This obstacle is based on the fact that judges are also human beings with compassion or compassion, especially for criminal acts committed by the defendant. The judge must have maturity in his heart and mind because to make a fair decision, and everyone has a sense of justice. The criminal acts committed by the defendant mainly were due to environmental, family, and economic factors. These factors become obstacles for judges in giving punishments for the crime of murder committed by the defendant.

The judge's obstacle is because in making his decision, he thinks that the defendant still has a long life or future, so there are still many things or opportunities and time for the defendant to improve himself and become a good person. This affects the judge where the judge feels that there will be a commutation of the sentence against the defendant, but on the other hand, the judge must also empathize with the victim's family. The judge in giving the sentence is the heart factor that will speak.

\section{b) External Factors}

External factors that hinder the law from eradicating the crime of murder committed by the defendant are outside the judge himself. 
In the trial room that took place, many parties were involved and concerned in the case. Starting from the defendants, witnesses, public prosecutors to lawyers. But it could also arise from other parties, namely:

1. Defendant's statement. During the trial, the judge needs information from the defendant himself about the crime he committed. The defendant's statement may not match what he said. For that, the judge must be observant in exploring how the defendant's contention is.

2. Witness Statement. The judge has a problem hearing the witnesses' testimony if the witness does not testify according to what should have happened. For that, the judge must also be able to connect or harmonize one witness with another.

3. Evidence. The control factor experienced by the judge is evidence that is lacking or has been lost. There is an obstacle for the judge because the more evidence there is, the easier it is to resolve the case and vice versa.

Although there are various obstacles or obstacles experienced by judges in giving consideration and making their decisions, all existing obstacles can be resolved with multiple efforts and a sense of responsibility from the parties as law enforcers. As for efforts to overcome existing barriers, the judge can see the information from the Public Prosecutor, and conduct deliberation with other Judges to provide appropriate considerations and decisions to the parties at trial, so that all parties can accept the judge's decision.

\section{Conclusion}

Judges' considerations in deciding cases of premeditated murder are following the rights and powers of judges according to the Law on Judicial Powers Number 4 of 2004 and related laws. Judges in making decisions must meet juridical, sociological, and philosophical requirements. The decision handed down by the judge must be based on the facts of legal considerations and the facts contained in the trial, as well as sufficient and robust evidence. Constraints faced by judges in imposing criminal sanctions against defendants take into account the Criminal Code. In making a decision, the judge considers the facts revealed in court. As for the crime of murder, the judge's obstacle is the facts of the trial, such as evidence that is not difficult enough to prove that the defendant committed the act of taking another person's life as part of his intention. Because basically, the defendant commits an action without the defendant knowing the consequences of his actions.

\section{References}

[1] V. Mere and F. Santiago, "Implementation of Criminal in Replacement Fine in Criminal Acts of Corruption," 2021, doi: 10.4108/eai.6-3-2021.2306453.

[2] F. Santiago, "Bunga Rampai Catatan Hukum," Perpust. Nas. RI. Katalog Dalam Terbit., 2016.

[3] B. Purnomo, Pokok-pokok hukum acara pidana dan beberapa harapan dalam pelaksanaan Kitab Undang-undang Hukum Acara Pidana. Liberty, 1982.

[4] E. Y. Kanter and S. R. Sianturi, Asas-asas hukum pidana di Indonesia dan penerapannya. Storia Grafika, 2002.

[5] F. Paparang, "Urgensi Ratifikasi Konvensi Menentang Penyiksaan," Lex Adm., vol. III, no. 1, pp. 199-204, 2015.

[6] P. Bourdieu, "The Force of Law : Toward a Sociology of the Juridical Field The Force 
of Law : Toward a Sociology of," vol. 38, no. 5, 1987.

[7] E. E. Supriyanto, "Revitalization of Pancasila as a Solution to The Problems Faced by The Indonesian Nation," J. Pendidik. Nusant., vol. 1, no. 2, pp. 52-61, 2021.

[8] E. E. Supriyanto, "PENERAPAN NILAI-NILAI PANCASILA DALAM KEBIJAKAN EKONOMI DI KABUPATEN TEGAL 2009-2014 Eko Eddya Supriyanto," J. Polit., vol. 2, no. 1, 2016.

[9] D. F. Ceswara, "Manusia Dalam Sila Pancasila," Lex Sci. Law Rev., vol. 2, no. 2, pp. 227-241, 2018.

[10] Ahmad Zuhdi, "Perkembangan Metodologi Penelitian Hukum," J. Huk. dan Perad., vol. 1, no. 2, pp. 189-206, 2012. 